\title{
Wine Festivals as a Vehicle of Promotion of a Tourist Destination
}

\author{
Jesus Claudio Perez Galvez (Ph. D.) \\ Department of Applied Economics, University of Cordoba, \\ Agrifood Campus of International Excellence ceiA3, Spain \\ Email: dt1pegaj@uco.es \\ Guzman Antonio Muñoz Fernandez (Ph. D.) \\ Department of Business Administration, University of Cordoba, \\ Agrifood Campus of International Excellence ceiA3, Spain \\ Email: guzman.munoz@uco.es \\ Tomas Lopez-Guzman (Ph. D.) \\ Department of Applied Economics, University of Cordoba, \\ Agrifood Campus of International Excellence ceiA3, Spain \\ Email: tomas.lopez@uco.es
}

\section{Doi:10.5901/mjss.2015.v6n3s2p574}

\begin{abstract}
Gastronomic and wine festivals are becoming a vehicle to promote the gastronomic products of certain tourist destinations, some of them characterized by an important cultural identity. This paper presents an investigation into the wine festival with the Designation of Origin Montilla-Moriles in Spain, which consists in enterprises, mostly characterized by small farmer cooperatives undergoing hardships in the marketing of the product. The research presents the sociodemographic profile, the motivation of tourists attending the event and the satisfaction with such festivals. The main results of this research point to the significant educational level of visitors, their high level of income, the possibility of using these festivals either as a means of promotion or as a means of marketing and the need to strengthen the advertising campaigns of this type of wine .
\end{abstract}

Keywords: Wine festivals, motivation, socioeconomic development, designation of origin, Spain

\section{Introduction}

The development and consolidation of wine tourism are allowing rural geographic areas, that were traditionally away from the tourist flows, to strengthen tourism-related activities and at the same time, to enable the generation of additional income in these areas, for individuals and businesses, many of them constituted as agricultural cooperatives. On the other hand, wine tourism enables winemaking companies to sell in the actual winery and to promote the product for the consumption of wine in the place of origin of the traveller. To such end, promotion campaigns of the wine of the geographical area are required, targeting not only the local community but also the travellers. Wine festivals, where the wines produced by winemaking companies are presented, are one of the best showcases for promotion, especially for agricultural cooperatives, finding an ideal way to introduce their products to the local community and to tourists visiting this geographical area, to market them and make contact with companies dedicated to wine distribution (Santos, Sousa, and Marques, 2014). In recent years, different types of festivals focused on wine, gastronomy and olive oil have proliferated in both rural and urban geographical areas, which attract more and more travellers willing to learn new experiences and discover these territories through their gastronomy (Yuan and Yang, 2008).

The aim of this paper is to present research on the sociodemographic profile and motivation of tourists attending the wine festival held in the framework of the Designation of Origin (DO) Montilla-Moriles in the province of Cordoba, where each year (now in its Thirty-first edition) companies, most of them agricultural cooperatives from this DO, gather to publicize both the local community and outsiders their food and wine products, to promote this tourist route based on wine, to strengthen the marketing of their products and to expand distribution lines through trade agreements to be closed within the festival itself. The article is divided into seven sections. After this introduction, the second section makes 
reference to wine tourism and wine festivals; a third section presents an analysis of wine tourism in Spain and, more specifically, of the official Montilla-Moriles wine route; in the fourth section, the methodology used in the research is analysed; the fifth section shows the results of the research and its discussion. And finally, the sixth and seventh sections show the conclusions and references used.

\section{Literature Review}

Scientific research in the field of wine tourism is quite recent since the first publications in this field were conducted in Australia in the nineties of the twentieth century (Hall et al., 2000). And little by little, they have spread to other parts of the world. Focusing on Europe, academic studies that address the wine tourism have focused mainly on the creation and structuring of tourist routes, due to the importance they have always had in cultural destinations (Arslam, 2013). Among these studies we find the contributions of Bras et al. (2010) on the wine route of Bairrada (Portugal), investigations of Charters and Menival (2011) in the region of Champagne (France), the study of Jurincic and Bojnec (2009) in the region of Boriska Brda (Slovenia), the analysis performed by Asero and Patti (2011) in Sicily (Italy), research on the wine routes of Northern Greece (Alebaki and lakovidou, 2010) or the study of Soare et al. (2010) in Romania. Wine tourism can be defined as the experience of visiting vineyards, knowing wineries, attending wine festivals and wine demonstrations in which wine tasting and/or the experience for tourists of the attributes thereof are the main reason for visitors (Hall et al., 2000). There is no single profile of wine tourists, but also according to Charters and Ali-Knight (2002), the differentiation in terms of wine tourist profile is based on three different dimensions: the motivation of the traveller, the type of visit you make to that geographical area and the type of activities performed. These authors, and considering these dimensions, classify enotourists (or wine tourists) into four different types: wine lovers, wine connoisseurs, those interested in wine and initiators in wine.

The areas of research that are currently being developed regarding the relationship between tourism and wine are divided, according to Mitchell and Hall (2006), in the following seven lines of research: 1)wine tourism product, 2)wine tourism and regional development, 3)quantification of the number of visitors, 4)market segmentation of tourism demand, 5)behaviour of the wine tourists, 6)the nature of wine tourism visitor, 7)biosecurity and wine. Focusing on one of these lines of research, the wine tourism product, this line analyses the wine tourism experience and its relation with two economic activities, the winemaking industry and tourism. This research address four different points: the wineries, the wine festivals, the wine routes and other activities related to wine (wine museums, wine trade fairs, etc.). In this sense, wine festivals, as an event, establish a synergy between the trip and the wine (Yuan et al., 2005) and become a vehicle to increase the satisfaction of travellers who visit a given area, to increase the image of the great wineries in that geographical area and to strengthen the sales of small businesses that, in most cases, have difficulties in marketing the product (Lopez-Guzman et al., 2014) and even making this gastronomic product known to profiles of people, such as the youth, who are usually not so involved in the world of wine (Yuan and Jang, 2008). Thus, this paper focuses on this research.

Regarding the analysis of wine festivals, Mitchell and Hall (2006) point out that the celebration of these festivals is one of the main components of wine tourism, having conducted research that address different perspectives such as the geographic location of wine festivals, the analysis of the sociodemographic profile of visitors or how these festivals can be the seed for the promotion of wine in that geographic area. Four studies that examine the wine festivals found in the work of Houghton (2001), Yuan et al. (2008), Gagic et al. (2013) and Santos et al. (2014) may be highlighted. Houghton (2001) believes that wine festivals are a secondary attraction to visit a determined geographical area, unlike what happens, sometimes, with wine routes (the main motivation is to visit the wineries and taste their wines) and that in most cases, a significant movement occurs in terms of repeat visitors to these festivals. Meanwhile, Gagic et al. (2013) point out that wine festivals, linked to the pairing with local delicacies, allow tourists to know the geographical area they are visiting differently, improving visitors' experience itself and reinforcing the different sensory pathways of travellers. Yuan et al. (2008) study the relationship between attendance to such events and motivation of the people involved in them, the satisfaction level that generally involves participation in future events and, where appropriate, in conducting different routes. Finally, Santos et al. (2014) presents an investigation into the wine festival in Porto, Portugal, where he analyses the profile of visitors to the event, their motivation and buying behaviour.

\section{Wine Tourism in Spain}

The official wine routes in Spain began to hinge from the new millennium through the coupling of different tourist routes centred on wine. The aim was to create quality tourism products that would unite two of the most important economic 
activities in Spain, which are agriculture and tourism. Later, in 2009, this product was completed with gastronomy, thereby strengthening the tourist experience. The official name "Wine Routes of Spain" brings together a total of 21 routes, at the time when this paper was written (February 2015). Namely: Alicante, El Bierzo, Bullas, Emporda, Garnacho-Campo de Borja, Lleida-Costers del Segre, Jumilla, Marco de Jerez, Montilla-Moriles, Navarra, Penedes, Rias Baixas, Ribera del Duero, Ribera del Guadiana, Rioja Alavesa, Rioja Alta, Rueda, Serrania de Ronda, Somontano, UrielRequena and Yecla. With regard to scientific literature addressing wine tourism in Spain, early studies were approached by foreign writers and focused mainly in two of the most important wine producing areas of the country, La Rioja and the Sherry region (Gilbert, 1992 ; Hall and Mitchell, 2000). From 2000, as a result of the structuring of the official wine routes and of the socioeconomic and cultural importance that this type of tourism has acquired, scientific literature of Spanish researchers has become rampant. In this sense, literature addresses in depth various tourist routes in Aragon (MarzoNavarro and Pedraja-Iglesias, 2012), Condado de Huelva (De la Orden, 2012), Canary Islands (Alonso and Liu, 2012), Sherry region (Lopez-Guzman et al., 2014), Montilla-Moriles (Lopez-Guzman et al., 2009) or Valencia (Clemente Ricolfe et al., 2012).

Focusing on the Wine Festival of Montilla-Moriles, whose commercial name is Cata de Vino Montilla-Moriles (Montilla-Moriles Wine Tastings), it is held in spring in the city of Cordoba, since 1982, and it annually receives more than 80,000 visits (Jiménez, 2014). The objectives of this festival are both to publicize this product to tourists and to the local community, and to strengthen trade relations between different companies. The wines from this D.O. are produced under flor yeasts and oxidative ageing is carried out through a "criaderas and soleras" pyramid system in oak barrels. Thus, different types of wines that can be tasted in said festival; young, fino, amontillado, oloroso and Pedro Ximenez. This festival has its continuation through two other events that take place in this geographical area. The first is the Harvest Festival held in Montilla, heart of the D.O., on the first weekend of September and which is held to celebrate the harvest of grapes of different terrains that comprise the D.O. The second event is Aleluya del Vino Nuevo (Alleluia of New Wine), where the public presentation of the new vintage of wines made in each campaign takes place, and it is also held on the first weekend of the month of December in Montilla.

\section{Methodology}

The methodology for this research was based on conducting fieldwork to know the profile and valuations of tourists regarding the Wine Festival (Wine Tasting) of Montilla-Moriles held in the city of Cordoba in April 2014. The field work was conducted within the actual wine festival site, specifically when respondent tourists where tasting the wine.

The structure of the survey used in the research is based on various previous works (Charters and Ali-Knight, 2002; Carmichael, 2005; Getz and Brown, 2006; Dawson et al., 2011) and responds to the approach of four sections: 1) the embodiment of the trip and determining aspects based on the visit to the wine tasting; 2) attitudes and motivations related to the visit and wine consumption within the festival itself; 3) purchasing behaviour; and 4) the analysis of the sociodemographic characteristics of the respondent tourist.

The surveys were conducted during the days of celebration of the festival, from the 24th to the 27th of April, 2014. The survey was distributed in two languages (Spanish and English). As mentioned, the questionnaire was completed within the festival site. Participants completed the survey with complete independence, although the interviewers were present in case they had some kind of difficulty. The survey was completely anonymous. Previously, a pre-test of 20 surveys was conducted to detect possible deviations and errors. The total number of interviews returned was 679 , of which 518 correspond to those tourists who attended the festival during the days on which it was held. Of these, 403 were Spaniards and 105 were non-nationals. Among foreign respondents, foreign tourists from Britain, France and Italy stand out.

The selection of the interviews was conducted by simple random sampling among visitors who met the condition of being a tourist. Interviewers chose the tables distributed within the festival site itself randomly for carrying out the surveys. The first question asked to the selected people was whether their usual place of residence was the city of Cordoba, only continuing with the interview in case of a negative reply. No variable was used to stratify (for example, gender or country of origin) as this type of research had not been conducted in any Wine Tasting edition. The refusal rate to the survey was low and non-significant in terms of any variable. Neither do we know the exact number of tourists who have visited this wine festival in previous years although there is an estimated figure of 80,000 visitors, this being the data we use as target population. There is no record of any similar study having been made to this date, despite it being a festival that is consolidated over time. The survey was distributed during the days indicated proportionally in two different shifts (midday and evening). The number of surveys conducted was similar in the different days of the Wine Tasting, with the exception of April 27th (Sunday), where, and because it only opened for the midday shift, the number of surveys conducted was 
approximately half of those conducted the other days.

The items used are intended to respond to the indicators and measures proposed for the realization of a demand analysis proposed in order to make systematic comparisons between different wine festivals (Getz and Brown, 2006). Thus, a combination of technical issues were used through a Likert 5-point scale to judge the motivation and expectations, yes/no answers and both open and closed questions, where surveyed tourists were able to make their comments about this gastronomic experience. The total number of people visiting the wine tasting in 2014 was approximately 80,000. However, these data do not distinguish between local visitors and tourists. Table 1 shows the technical specifications of the research. A convenience sampling was used; this being commonly used in this type of research where respondents are available to be interviewed in a specific space and time (Finn et al., 2000). The reliability index according to Cronbach's Alpha was 0.778 . The high rate of reliability obtained reinforces the validity of the research work carried out (Nunnally and Bernstein, 1994).

Table 1: Technical details of the investigation

\begin{tabular}{|c|c|}
\hline Total number of visitors to the wine tasting (2014) & 80,000 visitors \\
\hline Sample & 518 surveys \\
\hline Procedure & Simple random sampling \\
\hline Performance period & April 24, 25, 26 and 27,2014 \\
\hline Sampling error & $4.29 \%$ \\
\hline Confidence level & $95.0 \% \mathrm{p}=\mathrm{q}=0,5$ \\
\hline Sample Control & Implementation and monitoring of the work by the authors of the research. \\
\hline
\end{tabular}

Source: Own elaboration.

The data collected were organized, tabulated and analysed using the IBM SPSS Statistics 19 program. Data processing was performed through the use of univariate and bivariate statistical tools.

\section{Results of the Investigation and Discussion}

Table 2 shows the sociodemographic characteristics of tourists surveyed in the Cordoba Wine Festival according to gender, age, place of origin, professional status, educational level and level of income. According to Table 2, the vast majority of tourists visiting this wine festival were from Spain (79.5\%), followed by the UK and France. As for the main regions of origin of tourists it was Andalusia, followed at a great distance by Extremadura, Valencia, Madrid and CastillaLa Mancha. Based on these data, further promotion of the Wine Festival of Montilla-Moriles would be required outside the Andalusian territory, both nationally and internationally, in order to seek a major tourism attraction. Regarding the educational level, tourists with university studies clearly stand out. In terms of age groups, they are mostly people under 50 years of age. This result implies a great potential for the future consumption of this type of wine. As for the purchasing power of visitors, they range between 1,000 and 2,500 euros.

An association was detected between the level of income and age (Pearson Chi-square coefficient $=82.287, p=$ 0.000 ) between the educational level and income level (Pearson Chi-square coefficient $=25.308, p=0.005$ ), between the professional category and income level (Pearson Chi-square coefficient $=58.742, p=0.000$ ) and between the professional category and gender (Pearson Chi-square coefficient= 16.941, $p=0.005$ ).

Table 2: Sociodemographic characteristics of tourists in the Wine Festival in Cordoba

\begin{tabular}{|c|c|c|c|c|c|}
\hline Variable & Category & Percentage & Variable & Category & Percentage \\
\hline $\begin{array}{l}\text { Gender } \\
(N=508)\end{array}$ & $\begin{array}{l}\text { Man } \\
\text { Woman }\end{array}$ & $\begin{array}{l}51.3 \% \\
48.7 \%\end{array}$ & $\begin{array}{l}\text { Region } \\
(N=403)\end{array}$ & $\begin{array}{c}\text { Andalusia } \\
\text { Extremadura } \\
\text { Valencia } \\
\text { Madrid } \\
\text { Castilla-La Mancha } \\
\text { Other }\end{array}$ & $\begin{array}{c}43.9 \% \\
8.4 \% \\
7.7 \% \\
7.2 \% \\
6.0 \% \\
26.8 \%\end{array}$ \\
\hline
\end{tabular}




\begin{tabular}{|c|c|c|c|c|c|}
\hline $\begin{array}{c}\text { Age } \\
(N=507)\end{array}$ & $\begin{array}{c}\text { Under } 30 \\
\text { 30-39 years old } \\
40-49 \text { years old } \\
50-59 \text { years old } \\
60 \text { years old or more }\end{array}$ & $\begin{array}{c}25.6 \% \\
33.7 \% \\
24.9 \% \\
11.3 \% \\
4.5 \%\end{array}$ & $\begin{array}{c}\text { Professional } \\
\text { category } \\
(\mathrm{N}=508)\end{array}$ & $\begin{array}{l}\text { Self-employed } \\
\text { Employed } \\
\text { Civil Servant } \\
\text { Housewife } \\
\text { Retired } \\
\text { Other }\end{array}$ & $\begin{array}{c}22.4 \% \\
45.3 \% \\
20.1 \% \\
4.5 \% \\
2.8 \% \\
4.9 \%\end{array}$ \\
\hline $\begin{array}{l}\text { Education } \\
(\mathrm{N}=501)\end{array}$ & $\begin{array}{l}\text { Primary } \\
\text { Secondary } \\
\text { University }\end{array}$ & $\begin{array}{c}4.5 \% \\
21.6 \% \\
73.9 \%\end{array}$ & $\begin{array}{l}\text { Country } \\
(\mathrm{N}=507)\end{array}$ & $\begin{array}{c}\text { Spain } \\
\text { The United Kingdom } \\
\text { France } \\
\text { Italy } \\
\text { USA } \\
\text { Other }\end{array}$ & $\begin{array}{c}79.5 \% \\
5.5 \% \\
2.6 \% \\
2.4 \% \\
1.8 \% \\
8.2 \% \\
\end{array}$ \\
\hline $\begin{array}{l}\text { Familiar income } \\
\qquad(N=443)\end{array}$ & $\begin{array}{l}\text { Less than } € 700 / \text { month } \\
\text { From } € 700 \text { to } € 1,000 \\
\text { From } € 1,001 \text { to } € 1,500 \\
\text { From } € 1,501 \text { to } € 2,500 \\
\text { Over } € 2,500\end{array}$ & $\begin{array}{l}12.0 \% \\
16.9 \% \\
35.9 \% \\
23.9 \% \\
11.3 \%\end{array}$ & & & \\
\hline
\end{tabular}

Source: Own elaboration.

Most tourists surveyed already knew the city (80.3\%) and were staying in the city at least for two nights. Let us recall that one of the major challenges of tourism in the city of Cordoba is to increase overnight stays, and events such as this festival can be used to achieve this objective. On the other hand, most visit the city accompanied by their partner (38.4\%) or by work colleagues or friends (38.2\%). Also, $45.4 \%$ indicated that they will attend the wine festival only one day. As for how to learn of this event, most of them were through friends (50.1\%) and from the experience of other years (24.3\%). This finding corroborates the already pointed idea for the need for further promotion of the Cata del Vino (Wine Tasting).

As for the motivation to attend the wine festival, Table 3 shows the main outcomes measured on a Likert scale of 5 points, being 1-very unimportant and 5-very important. According to the results, the main reasons to visit the Wine Festival are entertainment and socializing with colleagues and friends. Moreover, the motivation to contact exhibitors stands out negatively, thus making us believe that the festival as a meeting point of companies engaged in the structuring of marketing channels should be strengthened.

Table 3: Motivation to attend the Wine Festival of Cordoba

\begin{tabular}{|c|c|}
\hline Motivation & Rating \\
\hline Entertainment & 4.01 \\
\hline Socializing with colleagues and friends & 3.97 \\
\hline Knowing the customs of this geographical area & 3.80 \\
\hline It is another activity of my visit to Cordoba & 3.83 \\
\hline Spending a day out & 3.76 \\
\hline Tasting different kinds of wine & 3.63 \\
\hline Tasting gastronomic products & 3.43 \\
\hline Learning about the world of wine & 3.42 \\
\hline Making contacts with exhibitors & 2.76 \\
\hline
\end{tabular}

Source: Own elaboration.

As for wine, $77.4 \%$ of respondent tourists knew the Montilla-Moriles wine before visiting the city of Cordoba. Furthermore, $29.3 \%$ of tourists surveyed drink wine more than once a week. As for their preferences as to the type of wine, this is stated in Table 4. This question was multiple choices whereby the result is greater than 100 . The results show that respondent tourists preferred red wine, followed by white wine. In this regard, in recent years red grapes are being introduced in the geographical area in order to respond to new tastes demanded by the market and where this wine 
festival can be a good vehicle for display to potential customers.

Table 4: Distribution preferences of types of wines

\begin{tabular}{|c|c|}
\hline Type of wine & Percentage \\
\hline Red & $41.8 \%$ \\
\hline White & $39.3 \%$ \\
\hline Fino & $34.7 \%$ \\
\hline Cava & $10.3 \%$ \\
\hline
\end{tabular}

Source: Own elaboration.

Regarding Wine Festival of Cordoba, the most relevant assessments made by respondent tourists are shown in Table 5. Based upon the answers it can be concluded that the Wine Festival of Cordoba has a positive impact on the image of the city. Moreover, tourists point that it would be of interest to include in this Festival, activities such as music, and to strengthen the gastronomy through an appropriate pairing of wine and traditional cuisine of this geographical area. Regarding the degree of satisfaction with the visit to the wine tasting, the average, in a Likert scale of 5 points, is 4.19. Thus, $40.1 \%$ of tourists surveyed are very satisfied with the visit, while $44.7 \%$ are satisfied. An association was detected between the level of satisfaction and the country of origin (Pearson Chi-square coefficient $=193.456, p=0.000$ ) and between the level of satisfaction and the level of income (Pearson Chi-square coefficient $=40.066, P=0.005$ ).

Table 5: Rating of aspects of the Wine Festival of Cordoba

\begin{tabular}{|l|l|}
\hline Aspects & Rating \\
\hline The celebration of the tasting positively influences the image that I have of Cordoba. & \\
\hline Other sociocultural attractions such as music must be added to this type of events. & 4.37 \\
\hline Other products related to gastronomy must be added to this type of events. & 4.08 \\
\hline The public authorities should take an active part in organizing such events. & 3.07 \\
\hline A good or bad organization influences the number of visitors. & 3.92 \\
\hline Weather conditions affect the number of visitors. & 3.82 \\
\hline Ease of access, communication and parking influences the number of visitors. & 3.63 \\
\hline The lack of economic resources of citizens influences the number of visitors. & 3.56 \\
\hline A greater or lesser presence in the media influences the number of visitors. & 3.52 \\
\hline
\end{tabular}

Source: Own elaboration

\section{Conclusions}

Wine and gastronomic festivals have become in recent years a vehicle for promoting both agricultural products and the tourism destination. In this sense, different geographical areas in Spain have festivals to publicize their products and at the same time, to reinforce the importance they have, in tourist destinations, all in relation with the food and wine culture.

This article presents an analysis of the sociodemographic profile and the motivation of tourists visiting one of the more established wine festivals that exists in Spain, the Montilla-Moriles Wine Tasting, which is held every year in the city of Cordoba and where both residents and visitors gather to learn of the agricultural products originating in the area. The main research results point to the high educational level of foreign visitors, these being people aged around 40, a positive aspect reinforcing an increase in the introduction of this type of wine into this segment of the population. Moreover, we can also highlight the relevance that is increasingly granted to daily consumption of wine.

The main practical application of this research is to contribute to understand the reasons why tourists participate in this type of festivals in order to conceive tourism and cultural products related with agriculture, that best meet the needs of tourists which are at the same time compatible with a sustainable management. This research shows evidence on the 
diversity of reasons why visitors choose the wine festival as a tourist destination. Based on them, we have identified a motivational dimension called social-hedonistic. In terms of level of satisfaction, the results are high, although there are significant differences being clearly linked to the motivations of the visit. The greatest level of satisfaction is experienced, by far, by to tourists who have a wine and gastronomic interest. Satisfaction decreases slightly, but still remains high, in those tourists who basically seek enjoyment and/or socialization. These results have important implications for improving the Montilla-Moriles Wine Festival as a tourist destination, and with it, the commercial objectives of the wineries, taverns and restaurants who participate to retain, in future, prospective customers. In a competitive environment, such as the current one, a correct configuration and presentation of services and factors that determine visitor satisfaction is necessary. In this study it is determined that motivational variables related to wine and entertainment blend in the festival enclosure. The wine culture and pleasure in life are inextricably linked. In this sense, the festival organizers should be aware that tourists attending the event must leave with both needs covered. To do this, it is recommended from the social-hedonistic dimension, to improve the infrastructure to ensure a greater convenience and comfort of visitors - more shady spots, enabling areas with tables and chairs, reducing noise, among others - and connecting the will of wines with a greater offer of regional cuisine.

The main limitation of this research is based on the scarcity of data existing on the relationship between this wine festival and tourist attendance, so researchers had no prior information on the type of traveller who visits this festival, they didn't even have quantitative data. And we precisely consider this limitation to be one of the great inputs that this research contributes with.

As a future line of research, we recommend a study of both tourists and local residents to learn the ratings and motivations of both groups with respect to the wine festival whose conclusions allow the different public administrations and private companies working in the field of tourism and the promotion of the D.O. Montilla-Moriles have a better understanding of the types of visitors, their motivations and their perception, and most of all, to preserve and reinforce the Montilla-Moriles Wine Tasting.

\section{Acknowledgements}

The authors of this paper would like to thank the Montilla-Moriles D.O. for their help and support in conducting this research. And especially the Manager of this Designation of Origin for all the facilities provided for performing the field work.

\section{References}

Alebaki, M., \& lakovidou, O. (2010). Segmenting the Greek wine tourism market using a motivational approach. New Medit, 4, 31-40.

Alonso, A.D., \& Liu, Y. (2012). Old wine region, new concept and sustainable development: sinery entrepreneurs' perceived benefits from wine tourism on Spain's Canary Islands. Journal of Sustainable Tourism, 20 (7), 991-1009.

Arslam, M. (2013). Ancient routes, new destinations: Roman Road via Sebaste as a thematic cultural route. Mediterranean Journal of Social Sciences, 4 (10), 660-665

Asero, V., \& Patti, S. (2011). Wine tourism experience and consumer behaviour: the case of Sicily. Tourism Analysis, 16 (4), $443-460$.

Bras, J.M., Costa, C. \& Buhalis, D. (2010). Network analysis and wine routes: the case of the Bairrada wine route. The Service Industries Journal, 30 (10), 1621-1641.

Carmichael, B.A. (2005). Understanding the wine tourism experience for winery visitors in the Niagara region, Ontario, Canada. Tourism Geographies, 7(2), 185-204.

Clemente Ricolfe, J.S., Escriba-Pérez, C., Rodríguez-Barrio, J.E., \& Buitrago-Vera, J.M. (2012). The potential wine tourist market: the case of Valencia (Spain). Journal of Wine Research, 23 (2), 185-202.

Charters, S., \& Ali-Knight, J. (2002). Who is the wine tourist?. Tourism Management, 23, 311-319.

Charters, S., \& Menival, D. (2011). Wine tourism in Champagne. Journal of Hospitality and Tourism Research, 35 (1), $102-118$.

Dawson, H., Homes, M., Jacob, H., \& Wade, R.I. (2011). Wine tourism: winery visitation in the wine appellations of Ontario. Journal of Vacation Marketing, 17 (3), 237-246.

De la Orden, R. (2012). The satisfaction of wine tourist: causes and effects. European Journal of Tourism Research, 5 (1), 80-83.

Finn, M., Elliott-White, M., \& Walton, M. (2000). Tourism and leisure research methods: Data collection, analysis and interpretation. Harlow: Pearson Education.

Gagic, S.M., Tesanovic, D.V., Ivkoz-Dzigurski, A.C., Pivac, T.D., \& Jovicic, A.D. (2013). Motives and attitudes of food and drink festival visitors: A case study of Serbia. Journal of Food, Agriculture \& Environment, 11 (1), 1055-1059.

Getz, D., \& Brown, G. (2006). Critical success factors for wine tourism regions: A demand analysis. Tourism Management, 27, $146-158$.

Gilbert, D. C. (1992). Touristic development of a viticultural regions of Spain. International Journal of Wine Marketing, 4 (2), 25-32.

Jiménez G.N. (2014). La Cata de Montilla-Moriles supera las 80.000 visitas en otra edición de récord. eldiadecordoba.es. [Online] 
Available: http://www.eldiadecordoba.es/article/cordoba/1760559/la/cata/montillamoriles/supera/las/visitas/otra/edicion/record. html(June 28, 2014).

Hall, C.M., \& Mitchell, R. (2000). Wine tourism in the Mediterranean: A tool for restructuring and development. Thunderbird International Business Review, 42 (4), 445-465.

Hall, C.M., Sharples, L., Cambourne, B., \& Macionis, N. (2000). Wine tourism around the world: development, management and markets. Oxford: Elsevier.

Houghton, M. (2001). The propensity of wine festivals to encourage subsequent winery visitation. International Journal of Wine Marketing, 13 (3), 32-41.

Jurincic, I., \& Bojnec, S. (2009). Wine tourism development: the case of the wine district in Slovenia. Tourism: An International interdisciplinary Journal, 57 (4), 435-448.

López-Guzmán, T., Sánchez Cañizares, S., \& Rodríguez García, J. (2009). Wine routes in Spain: a case study. Tourism: An International Interdisciplinary Journal, 57 (4), 421-434.

López-Guzmán, T., Vieira-Rodríguez, A., \& Rodríguez-García, J. (2014). Profile and motivations of European tourists on the Sherry wine route of Spain. Tourism Management Perspectives, 11, 63-68.

Marzo-Navarro, M., \& Pedraja-Iglesias, M. (2012). Critical factors of wine tourism: incentives and barriers from the potential tourist's perspective. International Journal of Contemporary Hospitality Management, 24 (2), 312-334.

Mitchell, R., \& Hall, C.M. (2006). Wine tourism research: the state of play. Tourism Review International, 9 (4), $307-332$.

Nunnally, J.C., \& Bernstein, I.H. (1994). Psychometric theory. New York: McGraw-Hill.

Santos, A. , Sousa, A. \& Marques S. R. (2014). Perfil e segmentaçao do visitante de festivais de vinho: O evento EV-Essência do VinhoPorto. Turismo e Desenvolvimento, 21/22, 95-109.

Soare, I., Man, O, Costachie, S., \& Nedelcu, A. (2010). Viticultural potential and wine tourism in Romania. Journal of Tourism, 10, 68-74.

Yuan, J., Cai, L.A., Morrison, A.M. \& Linton, S. (2005). An analysis of wine festival attendees' motivations: A synergy of wine, travel and special events. Journal of Vacation Marketing, 11 (1), 41-58.

Yuan, J., \& Jang, S. (2008). The effects of quality and satisfaction on awareness and behavioural intentions: exploring the role of a wine festival. Journal of Travel Research, 46, 279-288.

Yuan, J., Morrison, A.M., Cai, L.A., \& Linton, S. (2008). A model of wine tourist behaviour: a festival approach. International Journal of Tourism Research, 10, 207-219. 